Article

\title{
Cr-Free, $\mathrm{Cu}$ Promoted Fe Oxide-Based Catalysts for High-Temperature Water-Gas Shift (HT-WGS) Reaction
}

\author{
Sagar Sourav ${ }^{(D)}$ and Israel E. Wachs *(D) \\ Operando Molecular Spectroscopy and Catalysis Research Laboratory, Department of Chemical \& Biomolecular \\ Engineering, Lehigh University, Bethlehem, PA-18015, USA; sas616@lehigh.edu \\ * Correspondence: iew0@lehigh.edu
}

Received: 19 February 2020; Accepted: 4 March 2020; Published: 6 March 2020

check for updates

\begin{abstract}
Ca}, \mathrm{Ni}, \mathrm{Co}$, and Ge promoters were examined as potential candidates to substitute for the current toxic $\mathrm{Cr}$ in $\mathrm{Cu}$-promoted Fe oxide-based catalysts for the HT-WGS reaction. The Ca and Ni promoters were found to improve catalyst performance relative to promotion with $\mathrm{Cr}$. The HS-LEIS surface analysis data demonstrate that $\mathrm{Ca}$ and $\mathrm{Ge}$ tend to segregate on the surface, while $\mathrm{Ni}, \mathrm{Co}$, and $\mathrm{Cr}$ form solid solutions in the $\mathrm{Fe}_{3} \mathrm{O}_{4}$ bulk lattice. The corresponding number of catalytic active sites, redox, and WGS activity values of the catalysts were determined with CO-TPR, $\mathrm{CO}+\mathrm{H}_{2} \mathrm{O}-\mathrm{TPSR}$, and SS-WGS studies, respectively. The poorer HT-WGS performances of the Ge and Co promoters are related to the presence of surface $\mathrm{Ge}$ and $\mathrm{Co}$ that inhibits catalyst redox ability, with the Co also not stabilizing the surface area of the $\mathrm{Fe}_{3} \mathrm{O}_{4}$ support. The Ni promoter uniformly disperses the $\mathrm{Cu}$ nanoparticles on the catalyst surface and increases the number of $\mathrm{FeO}_{\mathrm{x}}-\mathrm{Cu}$ interfacial redox sites. The Ca promoter on the catalyst surface, however, enhances the activity of the $\mathrm{FeO}_{\mathrm{x}}-\mathrm{Cu}$ interfacial redox sites. The $\mathrm{CO}+\mathrm{H}_{2} \mathrm{O}$ TPSR results reveal that the redox ability of the active sites follows the SS-WGS performance of the catalysts and show the following trend: $3 \mathrm{Cu} 8 \mathrm{CaFe}>3 \mathrm{Cu} 8 \mathrm{NiFe} \geq 3 \mathrm{Cu} 8 \mathrm{CrFe}>$ $3 \mathrm{Cu} 8 \mathrm{CoFe}>>3 \mathrm{Cu} 8 \mathrm{GeFe}$. Furthermore, all the catalysts followed a redox-type reaction mechanism for the HT-WGS reaction.
\end{abstract}

Keywords: HT-WGS; Fe oxide-based catalysts; Cr-free catalysts; structure-function relationship

\section{Introduction}

The water-gas shift (WGS) reaction converts $\mathrm{CO}$ in the presence of $\mathrm{H}_{2} \mathrm{O}$ into $\mathrm{CO}_{2}$ and $\mathrm{H}_{2}$, which aims at controlling $\mathrm{H}_{2}$ to $\mathrm{CO}$ ratio for the synthesis of $\mathrm{NH}_{3}$ and $\mathrm{CH}_{3} \mathrm{OH}$, production of synthetic fuels, etc. [1,2]. Due to reversible and exothermic nature of the WGS reaction (Equation (1)), industrially, the reaction is performed in several stages with different catalysts to attain greater $\mathrm{CO}$ equilibrium conversions [3,4]. The low-temperature water gas shift (LT-WGS) reaction is performed at $\sim 190-250{ }^{\circ} \mathrm{C}$ with copper-zinc-oxide based catalysts and a high-temperature water gas shift (HT-WGS) reaction is performed at $\sim 350-450{ }^{\circ} \mathrm{C}$ with iron oxide-based catalysts:

$$
\mathrm{CO}+\mathrm{H}_{2} \mathrm{O} \leftrightarrow \mathrm{CO}_{2}+\mathrm{H}_{2} \quad \Delta \mathrm{H}=-40.6 \mathrm{~kJ} / \mathrm{mol}
$$

Industrial HT-WGS catalysts mostly contain ( $80-90 \%$ by bulk weight) Fe oxide with $\mathrm{Cu}$ and $\mathrm{Cr}$ oxides added as promoters for improved activity [4]. Unfortunately, the hexavalent Cr (VI) present in the catalyst is a significant carcinogen [5] and has been the topic of intense research over the past decades, especially to find Cr-free HT-WGS catalysts. A thorough understanding of the structures and roles of various metal oxides present in $\mathrm{Cu} / \mathrm{Cr}-\mathrm{Fe}$ oxide catalysts, however, is needed for the rational design of a Cr-free catalyst for the HT-WGS reaction. In this regard, detailed in situ and 
operando spectroscopy studies have been undertaken to gain this information, along with identification and determination of the catalytic active site(s) and structure-function relationship for the $\mathrm{Cu} / \mathrm{Cr}-\mathrm{Fe}$ oxide-based HT-WGS catalysts.

It is now well established that the initial calcined catalysts contain both the bulk $\alpha / \gamma-\mathrm{Fe}_{2} \mathrm{O}_{3}$ phases that transform to bulk $\gamma$ - $\mathrm{Fe}_{2} \mathrm{O}_{3}$ phase after calcining in an oxidizing environment to $400{ }^{\circ} \mathrm{C}$ [6]. After exposure to WGS or r-WGS reaction conditions, the bulk $\gamma-\mathrm{Fe}_{2} \mathrm{O}_{3}$ phase $\left(\mathrm{Fe}^{3+}\right)$ slightly reduces and transforms to a bulk $\gamma-\mathrm{Fe}_{3} \mathrm{O}_{4}$ phase $\left(\mathrm{Fe}^{2+/ 3+}\right)$, which is the equilibrated bulk structure of iron oxide under WGS or r-WGS reaction conditions [6-9].

The $\mathrm{Cu}$ promoter in the initial calcined catalyst is present as $\mathrm{Cu}^{+2}$, which is distributed uniformly throughout the $\mathrm{Fe}_{2} \mathrm{O}_{3}$ bulk lattices [7]. After activation under the WGS or r-WGS reaction conditions, the $\mathrm{Cu}^{+2}$ reduces to metallic $\mathrm{Cu}$, which migrates to the surface and sinters to form nanoparticles (NPs). Although the metallic $\mathrm{Cu}$ NPs can be easily oxidized to $\mathrm{Cu}^{+2}$ by both $\mathrm{CO}_{2}$ or $\mathrm{H}_{2} \mathrm{O}$, the $\mathrm{Cu}$ remains as metallic $\mathrm{Cu}$ NPs during WGS or $\mathrm{r}-\mathrm{WGS}$ reactions because of the presence of the reducing $\mathrm{H}_{2}$ and $\mathrm{CO}$ gases. For the supported $3 \mathrm{Cu} / 8 \mathrm{Cr}-\mathrm{Fe}$ oxide catalyst, TEM and HS-LEIS analysis revealed that the $\mathrm{Cu}$ NPs are $\sim 3 \mathrm{~nm}$ in size [7]. Interestingly, the HS-LEIS depth analysis also showed that $\sim 1 / 3 \mathrm{rd}$ of the surface of the metallic $\mathrm{Cu}$ NPs is covered by the $\mathrm{FeO}_{x}$ species by the so-called strong metal-support interaction (SMSI) [10] effect. In a subsequent study, the SMSI effect was thoroughly investigated for the supported $\mathrm{Cu} / \mathrm{Cr}-\mathrm{Fe}$ based $\mathrm{HT}-\mathrm{WGS}$ catalysts, and $\mathrm{FeO}_{\mathrm{x}}$ sites in close vicinity of metallic $\mathrm{Cu} \mathrm{NPs}$ (or the $\mathrm{FeO}_{\mathrm{x}}-\mathrm{Cu}$ interface) were reported as the catalytic active site for the WGS reaction [11]. The metallic $\mathrm{Cu}$ NPs increase TOF value by $\sim 3-4 x$ and, thus, serve as chemical promoters for the WGS reaction $[7,12]$. The reaction rate enhancement is related to the improved surface chemical characteristics of the $\mathrm{FeO}_{\mathrm{x}}$ overlayer (e.g., a strong affinity for $\mathrm{CO}$ adsorption [13] and $\mathrm{H}_{2} \mathrm{O}$ dissociation [13]).

The Cr-oxide promoter in the initial oxidized catalyst is mostly surface-enriched, as surface dioxo $(\mathrm{O}=)_{2} \mathrm{Cr}^{+6} \mathrm{O}_{2}$ sites and residual chromia is present as $\mathrm{Cr}^{+3}$ dissolves in the $\mathrm{Fe}_{2} \mathrm{O}_{3}$ bulk lattice [7]. Under WGS or r-WGS reaction environments, the surface $\mathrm{Cr}^{+6}$ sites reduce $\left(\mathrm{Cr}^{+3}\right)$ and form a solid solution with the $\mathrm{Fe}_{3} \mathrm{O}_{4}$ bulk lattice. The $\mathrm{Cr}^{+3}$ in the bulk $\mathrm{Fe}_{3} \mathrm{O}_{4}$ lattice acts as a structural stabilizer that inhibits sintering and overreduction of iron oxide to $\mathrm{FeO}$ or metallic $\mathrm{Fe}[5,8,14]$. This is reflected by an increase in surface area and total number of active sites $[7,12]$. Additionally, in situ XANES measurements have demonstrated that re-oxidation of $\mathrm{Cr}^{+3}$ in the lattice to $\mathrm{Cr}^{+6}$ by $\mathrm{CO}_{2}$ or $\mathrm{H}_{2} \mathrm{O}$ is not possible since the $\mathrm{Cr}^{+6} \leftrightarrow \mathrm{Cr}^{+3}$ redox cycle does not take place. ${ }^{7}$ This suggests that $\mathrm{Cr}$ does not directly participate in the WGS reaction supported by the nearly same TOF values for the $\mathrm{Cr}-\mathrm{Fe}$ and pure Fe oxide catalysts $[7,12]$.

The above summary of the $\mathrm{Cu}-\mathrm{Cr}-\mathrm{Fe}$ oxide WGS catalyst system suggests that ideal substitutes for the toxic $\mathrm{Cr}$ promoter should possess the following properties: (i) be able to stabilize the surface area of $\mathrm{Fe}_{3} \mathrm{O}_{4}$ against excessive thermal and mechanical sintering, (ii) form a solid solution with the $\mathrm{Fe}_{3} \mathrm{O}_{4}$ bulk lattice to inhibit overreduction of iron oxide, and (iii) not interfere with the formation of highly active $\mathrm{FeO}_{x}-\mathrm{Cu}$ interfacial sites.

Several reviews of Cr-free HT-WGS catalysts have been published in the literature [15-17] and are only briefly summarized here. Chinchen was the first to examine $\mathrm{Ca}, \mathrm{Ce}$, and $\mathrm{Zr}$ promoters without $\mathrm{Cu}$, based on cation size and oxidation number [18]. The $\mathrm{Ce}-\mathrm{Fe}$ and $\mathrm{Zr}-\mathrm{Fe}$ mixed oxides were found to have higher surface areas, but lower activity than the standard $\mathrm{Cr}-\mathrm{Fe}$ oxide catalyst. Rethwisch and Dumesic studied the effect of $\mathrm{Zn}$ and $\mathrm{Mg}$ as bulk oxides in iron $\left(\mathrm{ZnFe}_{2} \mathrm{O}_{4}\right.$ and $\left.\mathrm{MgFe}_{2} \mathrm{O}_{4}\right)$ but found that these two oxide phases result in lower WGS activity than the $\mathrm{Fe}_{3} \mathrm{O}_{4}$ bulk oxide catalyst [19]. Pereira et al. investigated the promotion effect of $\mathrm{Co}$ on iron oxide, in the absence of $\mathrm{Cu}$ oxide [20]. No promotion effect of $\mathrm{Co}$ was observed for low $\mathrm{Co} / \mathrm{Fe}$ molar ratios ( 0.05). For a high Co concentration ( $\mathrm{Co} / \mathrm{Fe}$ molar ratio of 1), cobalt ferrite $\left(\mathrm{CoFe}_{2} \mathrm{O}_{4}\right)$ and $\mathrm{Co}_{3} \mathrm{Fe}_{7}$ alloy formation was observed, resulting in increased surface area, higher WGS activity, and improved resistance against overreduction of magnetite. Lee et al. investigated the promotion of $\mathrm{Ni}$, along with $\mathrm{Co}, \mathrm{Zn}$, and $\mathrm{Cs}$, and found that Ni increased surface area and resulted in higher CO conversion during WGS, but also lead to an undesirable side reaction of $\mathrm{CO}$ methanation [21-23]. Other researchers found $\mathrm{Cu}$ promoted $\mathrm{Ni}-\mathrm{Fe}$ oxide catalysts more active due to increased lattice strain, decreased lattice oxygen binding energy, 
higher surface area, and reducibility of iron oxide [24]. Among the Cr-free HT-WGS catalysts, Al has received the most attention [25-27] and a corresponding study with $\mathrm{Al}$ was recently reported [9]. The high WGS activity of the $\mathrm{Cu} / \mathrm{Al}-\mathrm{Fe}$ catalysts was attributed to the high surface area, excellent reducibility, and high $\mathrm{CO}$ conversion. A series of $\mathrm{Mn}, \mathrm{Co}, \mathrm{Ni}$, and $\mathrm{Cu}$ promoted $\mathrm{Fe} / \mathrm{Nb}$ catalysts have also been examined for HT-WGS reactions [28]. The co-doping of $\mathrm{Nb}$ with the transition metal oxides was found to improve catalytic activity due to increased lattice strain and facile $\mathrm{Fe}^{+2} \leftrightarrow \mathrm{Fe}^{+3}$ redox cycle. However, it is important to note that most of these studies lacked in situ spectroscopic information and were conducted on the initially oxidized catalysts. The above conclusions of the Cr-free WGS catalysts are debatable since recent in situ and operando spectroscopy studies have shown that Fe-based HT-WGS catalyst structures are dynamic in nature.

In the present study, the oxides of $\mathrm{Ca}, \mathrm{Co}, \mathrm{Ni}$, and $\mathrm{Ge}$ in $\mathrm{Cu}$ were examined as promoters of $\mathrm{Cr}$-free Fe oxide catalysts for a HT-WGS reaction since these oxides form solid solutions with the $\mathrm{Fe}_{3} \mathrm{O}_{4}$ bulk lattice [29]. Although these metals have been previously investigated, the present study is unique because (i) experiments were conducted on catalysts activated under the WGS or r-WGS reaction conditions to accommodate the dynamic nature of the catalyst structure and (ii) without exposure to air that could oxidize and change the pyrophoric catalyst. In addition, unique characterization (e.g., High Sensitivity Low Energy Ion Scattering (HS-LEIS) Spectroscopy to determine the elemental composition of the outermost surface layers) and chemical probe reactions were undertaken (COTemperature Programmed Reduction (TPR) and $\mathrm{CO}+\mathrm{H}_{2} \mathrm{O}$-Temperature Programmed Surface Reaction (TPSR) experiments to gain insight into the number of catalytic active sites, surface redox ability, reaction mechanism, and TOF values) to gain a fundamental understanding of the functioning of non-Cr promoters in the $\mathrm{Cu}$-Fe oxide HT-WGS catalytic system.

\section{Results}

\subsection{BET Surface Area}

The BET surface area of the freshly calcined 3Cu8MFe $(\mathrm{M}=\mathrm{Cr}, \mathrm{Ca}, \mathrm{Ni}, \mathrm{Co}, \mathrm{Ge})$ catalysts are shown in Figure 1. The commercial 3Cu8CrFe catalyst has a surface area of $\sim 78 \mathrm{~m}^{2} / \mathrm{g}$. Among all non-Cr catalysts, $3 \mathrm{Cu} 8 \mathrm{CaFe}$ exhibits the highest surface area $(\sim 2.2 \mathrm{x}$ compared to $3 \mathrm{Cu} 8 \mathrm{CrFe}$ catalyst). Both $3 \mathrm{Cu} 8 \mathrm{NiFe}$ and $3 \mathrm{Cu} 8 \mathrm{GeFe}$ catalysts also have a much higher surface area $(\sim 1.4 \mathrm{x}$ and $\sim 1.7 \mathrm{x}$, respectively) than the $3 \mathrm{Cu} 8 \mathrm{CrFe}$ catalyst. On the other hand, the fresh $3 \mathrm{Cu} 8 \mathrm{CoFe}$ catalyst has $\sim 17 \%$ less surface area than the $3 \mathrm{Cu} 8 \mathrm{CrFe}$ catalyst.

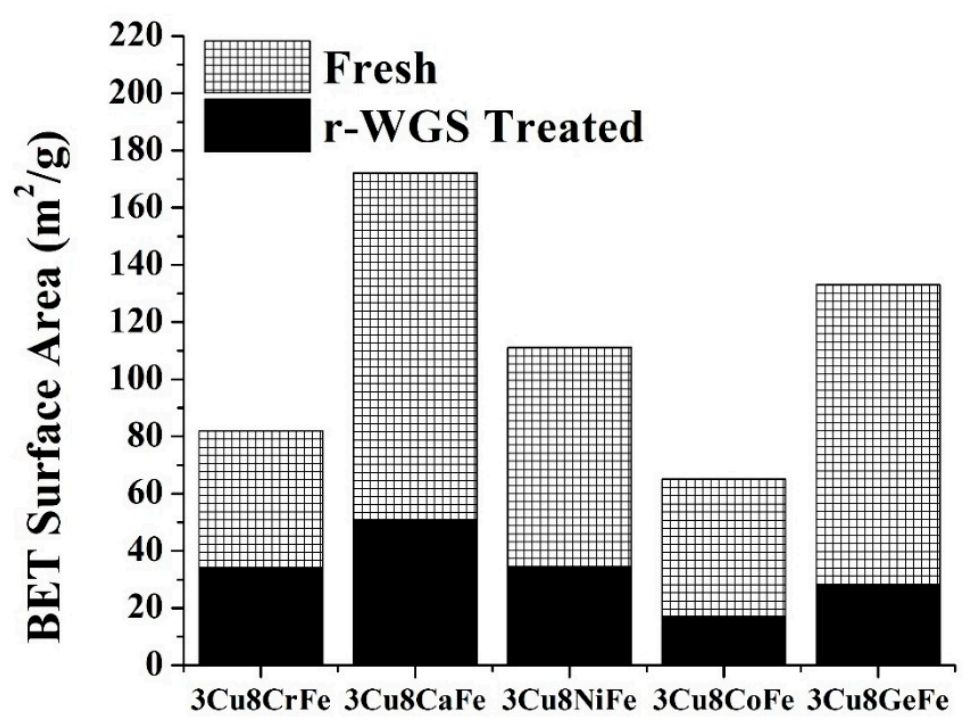

Figure 1. BET surface area of the freshly calcined catalysts and catalysts treated under r-WGS conditions $\left(500{ }^{\circ} \mathrm{C}, 2 \mathrm{~h}\right)$. 
After treatment of the catalysts under r-WGS reaction conditions, the surface area changes drastically. The commercial 3Cu8CrFe catalyst has a surface area of $\sim 34 \mathrm{~m}^{2} / \mathrm{g}$, only $43 \%$ of the fresh catalyst surface area. Among non-Cr promoters, only the $3 \mathrm{Cu} 8 \mathrm{CaFe}$ catalyst exhibits a higher surface area $\left(\sim 51 \mathrm{~m}^{2} / \mathrm{g}\right)$ than the $3 \mathrm{Cu} 8 \mathrm{CrFe}$ catalyst after the r-WGS treatment. The $3 \mathrm{Cu} 8 \mathrm{NiFe}$ catalyst has a similar surface area compared to the $3 \mathrm{Cu} 8 \mathrm{CrFe}$ catalyst. On the other hand, the $3 \mathrm{Cu} 8 \mathrm{CoFe}$ and $3 \mathrm{Cu} 8 \mathrm{GeFe}$ catalysts have a much lower surface area compared to the $3 \mathrm{Cu} 8 \mathrm{CrFe}$ catalyst.

\subsection{High Sensitivity Low Energy Ion Scattering (HS-LEIS)}

The surface of the catalysts was examined by High-Sensitivity Low Energy Ion Scattering (HS-LEIS) Spectroscopy, a highly surface-sensitive technique that analyzes the topmost surface layer $(\sim 0.3 \mathrm{~nm})$ of a solid, as well as depth profiling by surface sputtering through $\mathrm{Ar}^{+}$gas ions. Two types of ions- $\mathrm{He}^{+}$ for a lighter element like $\mathrm{Ca}$ and $\mathrm{Ne}^{+}$for heavier elements like $\mathrm{Fe}, \mathrm{Co}, \mathrm{Ni}, \mathrm{Cu}$, and $\mathrm{Ge}$-were used for probing. The HS-LEIS depth profile for the $3 \mathrm{Cu} 8 \mathrm{CrFe}$ catalyst, both initially calcined and activated under r-WGS reaction conditions, has been reported previously [7] (reproduced in Figure 2) and the findings were summarized in the introduction section. In the current study, the surfaces of the $3 \mathrm{Cu} 8 \mathrm{CaFe}, 3 \mathrm{Cu} 8 \mathrm{NiFe}, 3 \mathrm{Cu} 8 \mathrm{CoFe}$, and $3 \mathrm{Cu} 8 \mathrm{GeFe}$ catalysts were analyzed; the HS-LEIS intensity of each element as a function of depth are presented in Figure 2.

3Cu8CaFe: For the initially calcined catalyst, the intensity of the Ca signal continuously decreases with depth, indicating that $\mathrm{Ca}$ is surface enriched. The corresponding intensity of the $\mathrm{Cu}$ signal, however, increases with depth, indicating that $\mathrm{Cu}$ is surface depleted and is more concentrated below the outermost surface layer in the bulk lattice. After activation of the catalyst under r-WGS reaction conditions, no noticeable change in the intensity of the Ca signal takes place since Ca remains surface enriched. The corresponding intensity of the $\mathrm{Cu}$ signal, however, decreases by $\sim 50 \%$, reflecting sintering of the $\mathrm{Cu}$ (>4 nm metallic $\mathrm{Cu}$ NPs, see Figure S1). The increasing intensity of the Cu signal from the topmost layers with depth suggests that the surface of the $\mathrm{Cu}^{0} \mathrm{NPs}$ is partially covered by other metal oxides (Ca and/or Fe-oxides).

3Cu8NiFe: For the initially calcined catalyst, the intensity of the Ni signal increases with depth, indicating that $\mathrm{Ni}$ is surface depleted and more concentrated in the bulk lattice. The intensity of the $\mathrm{Cu}$ signal, however, modestly decreases with sputtering depth, reflecting its surface enrichment. The higher concentration of $\mathrm{Cu}$ than $\mathrm{Ni}$ in the topmost layers is supported by the greater intensity of the $\mathrm{Cu}$ signal than the Ni signal (the similar HS-LEIS sensitivity factors of both $\mathrm{Ni}$ and $\mathrm{Cu}$ allow us to make this statement; see Figure S2a). After activation of the 3Cu8NiFe catalyst under r-WGS conditions, the overall intensity of the Ni signal slightly decreases and continuously increases with depth profiling. The increasing intensity of the $\mathrm{Ni}$ signal with sputtering depth is reflected by the migration of $\mathrm{Ni}$ into the $\mathrm{Fe}_{3} \mathrm{O}_{4}$ bulk lattice. In contrast, the overall intensity of the $\mathrm{Cu}$ signal is higher than that of the calcined catalyst, suggesting that the formed metallic $\mathrm{Cu}$ NPs are comparatively smaller in size $(\sim 2.5 \mathrm{~nm}$, see Figure S2b). Furthermore, the increasing intensity of the $\mathrm{Cu}$ signal with depth reflects the presence of $\mathrm{FeO}_{x}$ overlayers on metallic $\mathrm{Cu}$ NPs, since Ni tends to diffuse into the $\mathrm{Fe}_{3} \mathrm{O}_{4}$ bulk lattice [29].

3Cu8CoFe: For the initially calcined catalyst, the intensity of the Co signal modestly increases with sputtering, reflecting the greater concentration of $\mathrm{Co}$ in the Fe oxide bulk lattice. The intensity of the $\mathrm{Cu}$ signal, however, is relatively constant, indicating a uniform distribution of $\mathrm{Cu}$ in the outermost surface layer and the Fe oxide bulk lattice. After activation under r-WGS reaction conditions, the intensity of the Co signal slightly decreases in the outermost layer and increases in the layers below the outermost layer. This trend in HS-LEIS intensity of the Co signal is consistent with the migration of $\mathrm{Co}$ from the outermost layer into the $\mathrm{Fe}_{3} \mathrm{O}_{4}$ bulk lattice [20]. The overall intensity of the $\mathrm{Cu}$ signal is reduced after activation consistent with the formation of metallic $\mathrm{Cu}$ NPs on the outermost surface. The decreasing intensity of the $\mathrm{Cu}$ signal with depth indicates that $\mathrm{Cu}$ is surface enriched and may not even be decorated with Fe and Co oxide overlayers. 
3Cu8GeFe: For the initially calcined catalyst, the decreasing intensity of the Ge signal decreases with depth, indicating surface enrichment of Ge oxide. The corresponding intensity of the $\mathrm{Cu}$ with sputtering depth is relatively constant consistent with the uniform distribution of $\mathrm{Cu}$ between the outermost surface layer and deeper layers. After catalyst activation under r-WGS reaction conditions, the intensity of the Ge signal was slightly decreased and still exhibited the same trend with depth, consistent with surface enrichment of Ge. The intensity of the $\mathrm{Cu}$ signal, however, was drastically diminished, suggesting the formation of very large metallic $\mathrm{Cu}$ NPs and/or thick oxide overlayers.
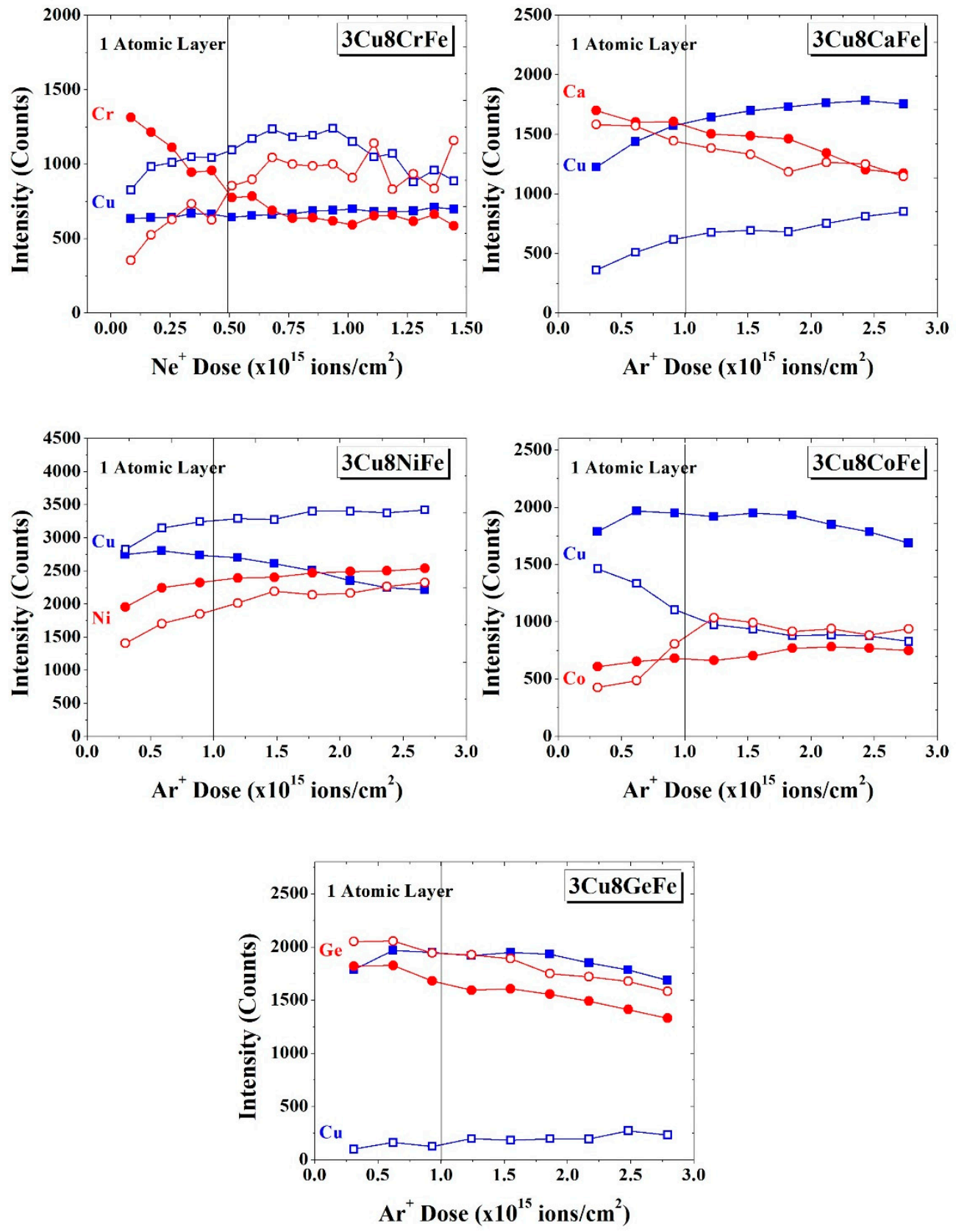

Figure 2. The HS-LEIS elemental intensity of $\mathrm{Cu}$ and $\mathrm{M}(\mathrm{M}=\mathrm{Ca}, \mathrm{Ni}, \mathrm{Co}$ and $\mathrm{Ge}$ ) of calcined (solid symbols) and r-WGS reaction activated (empty symbols) for the 3Cu8MFe catalysts as a function of $\mathrm{Ar}^{+}$ ion dose. The vertical dashed line indicates $\mathrm{Ar}^{+} / \mathrm{Ne}^{+}$sputtering of one atomic layer. For reference, HS-LEIS elemental analysis of the $3 \mathrm{Cu} 8 \mathrm{CrFe}$ catalyst is also included in the figure, adapted with permission from [7]. 


\subsection{CO-Temperature Programmed Reduction (TPR)}

The reducibility of the catalysts was probed by the CO-TPR experiment (shown in Figure 3). The TPR profiles of all the catalysts, except for $3 \mathrm{Cu} 8 \mathrm{GeFe}$, majorly exhibit two reduction zones. The low-temperature reduction is due to the removal of highly active surface lattice oxygen and the high-temperature reduction can be attributed to the slow removal of bulk lattice $\mathrm{O}$ atoms [7]. Further, these catalysts show a peak reduction temperature, $T_{p}$, within a narrow temperature range (150 to 158 ${ }^{\circ} \mathrm{C}$ ), suggesting a comparable reducibility characteristic. On the other hand, the reduction of $3 \mathrm{Cu} 8 \mathrm{GeFe}$ catalyst by $\mathrm{CO}$ exhibits $\mathrm{T}_{\mathrm{p}}$ at a much higher temperature. This indicates that the $3 \mathrm{Cu} 8 \mathrm{GeFe}$ catalyst is much less reducible in nature compared to the other catalysts.

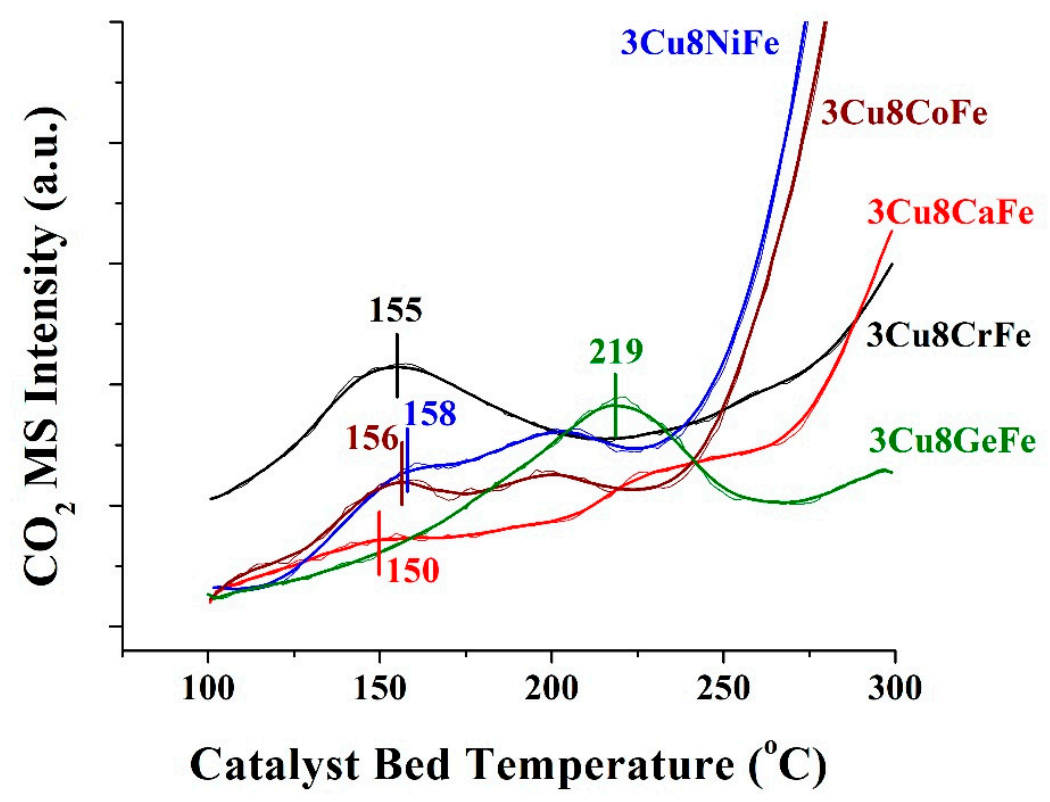

Figure 3. $\mathrm{CO}_{2}$ evolution of $3 \mathrm{Cu} 8 \mathrm{MFe}$ catalysts $(\mathrm{M}=\mathrm{Cr}, \mathrm{Ca}, \mathrm{Ni}, \mathrm{Co}$ and $\mathrm{Ge})$ as a function of catalyst bed temperature. The thin zigzag line represents the actual data points and the bold solid line passing through the data points is the moving average for the respective data points in each curve. Calibration of the $\mathrm{CO}_{2}$ mass spectrometer signal, number of catalytic active redox sites $\left(\mathrm{N}_{\mathrm{s}}\right)$ for each catalyst, was achieved with CO-Temperature Programmed Reduction of known quantities of bulk CuO (see calibration curve in Figure S3).

The number of catalytic active sites present in each catalyst can also be quantified from the area under the respective $\mathrm{CO}_{2}$ evolution TPR curves. For this purpose, the number of reducible sites corresponding only to the lowest $\mathrm{T}_{\mathrm{p}}$ (marked in Figure 3 ) was considered. This assumption was based on the fact that the sites active at the lowest temperature for CO-oxidation possess a much higher activity at elevated temperature and dominate the overall catalytic activity. The number of reducible catalytic active sites $\left(\mathrm{N}_{\mathrm{s}}\right)$ for each catalyst are listed in Table 1.

\section{4. $\mathrm{CO}+\mathrm{H}_{2} \mathrm{O}$ Temperature Programmed Surface Reaction (TPSR)}

The redox ability of the catalytic active sites was chemically probed with $\mathrm{CO}+\mathrm{H}_{2} \mathrm{O}-\mathrm{TPSR}$ spectroscopy; the resulting spectra are shown in Figure 4. Formation of $\mathrm{CO}_{2}$ reflects the ability of the catalytic sites to reduce and oxidize $\mathrm{CO}$, while the formation of $\mathrm{H}_{2}$ reflects the ability of the reduced catalytic active sites to be oxidized by $\mathrm{H}_{2} \mathrm{O}$. For the $3 \mathrm{Cu} 8 \mathrm{CrFe}$ catalyst, the $\mathrm{CO}_{2}$ evolution initiates at $\sim 115^{\circ} \mathrm{C}$ and exhibits a much-delayed $\mathrm{H}_{2}$ light-off temperature of $\sim 225^{\circ} \mathrm{C}$. For the $3 \mathrm{Cu} 8 \mathrm{CaFe}$ catalyst, $\mathrm{CO}_{2}$ and especially $\mathrm{H}_{2}$ evolution started at much lower temperatures $\left(102{ }^{\circ} \mathrm{C}\right.$ and $178{ }^{\circ} \mathrm{C}$, respectively) compared to the $3 \mathrm{Cu} 8 \mathrm{CrFe}$ catalyst. The $3 \mathrm{Cu} 8 \mathrm{NiFe}$ catalyst exhibits a delayed $\mathrm{CO}_{2}$ evolution $\left(\sim 132^{\circ} \mathrm{C}\right)$, but an earlier $\mathrm{H}_{2}$ evolution $\left(212{ }^{\circ} \mathrm{C}\right)$ compared to the $3 \mathrm{Cu} 8 \mathrm{CrFe}$ catalyst. Finally, both the $3 \mathrm{Cu} 8 \mathrm{CoFe}$ 
and $3 \mathrm{Cu} 8 \mathrm{GeFe}$ (see Figure $\mathrm{S} 4$ for $\mathrm{H}_{2} \mathrm{O}$ evolution temperature) catalysts display very slow evolutions (much delayed light off temperatures) for both $\mathrm{CO}_{2}$ and $\mathrm{H}_{2}$, compared to the $3 \mathrm{Cu} 8 \mathrm{CrFe}$ catalyst. The redox ability (based on $\mathrm{H}_{2}$ evolution temperature) of the catalytic active sites present in the respective catalysts follows the trend $3 \mathrm{Cu} 8 \mathrm{CaFe}>3 \mathrm{Cu} 8 \mathrm{NiFe} \sim 3 \mathrm{Cu} 8 \mathrm{CrFe}>3 \mathrm{Cu} 8 \mathrm{CoFe}>>3 \mathrm{Cu} 8 \mathrm{GeFe}$.
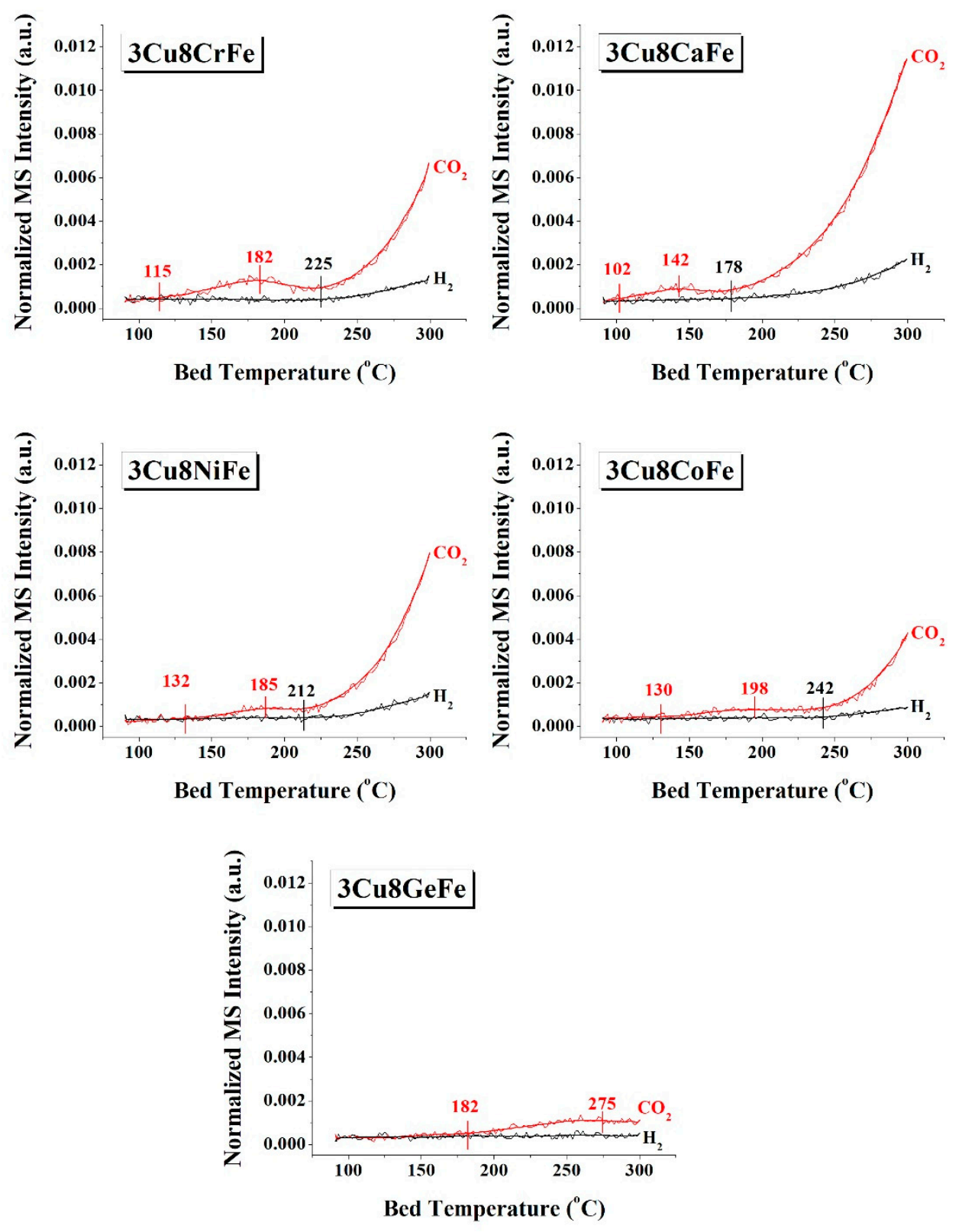

Figure 4. Evolution of $\mathrm{H}_{2}$ and $\mathrm{CO}_{2}$ as a function of catalyst temperature for various $3 \mathrm{Cu} 8 \mathrm{MFe}$ catalysts $(\mathrm{M}=\mathrm{Cr}, \mathrm{Ca}, \mathrm{Ni}, \mathrm{Co}$, and $\mathrm{Ge})$. The thin zigzag line represents the actual data points and the bold solid line passing through the data points is the moving average for the respective data points in each curve.

\subsection{SS-WGS Activity}

The SS-WGS activity values for all the promoted catalysts at $340{ }^{\circ} \mathrm{C}$ are presented in Table 1 . The $\mathrm{SS}$ activity follows the order $3 \mathrm{Cu} 8 \mathrm{CaFe}>3 \mathrm{Cu} 8 \mathrm{NiFe}>3 \mathrm{Cu} 8 \mathrm{CrFe}>3 \mathrm{Cu} 8 \mathrm{CoFe}>>3 \mathrm{Cu} 8 \mathrm{GeFe}$. From the knowledge of the activity and $\mathrm{N}_{\mathrm{s}}$ values for each catalyst, it was possible to quantify the TOF values (also given in Table 1). The activation energy values for the catalysts were determined using Arrhenius plots (see Figure S5) and included in Table 1. All the catalysts, with the exception of 3Cu8GeFe that showed a much lower activation energy value, exhibited comparable activation energy values. 
Table 1. Number of catalytic active sites $\left(\mathrm{N}_{\mathrm{s}}\right)$, the $\mathrm{CO}_{2}$ evolution peak reduction temperatures $\left(\left[\mathrm{T}_{\mathrm{p}}\right]_{\mathrm{rds}}\right)$, reaction rate constants, $\left[k_{\mathrm{rds}}\right]_{400}{ }^{\circ} \mathrm{C}$ from $\left[\mathrm{T}_{\mathrm{p}}\right]_{\mathrm{rds}}$, SS-WGS activity, TOF and activation energy values of the $3 \mathrm{Cu} 8 \mathrm{MFe}$ catalysts $(\mathrm{M}=\mathrm{Cr}, \mathrm{Ca}, \mathrm{Ni}, \mathrm{Co}$ and $\mathrm{Ge})$.

\begin{tabular}{|c|c|c|c|c|c|c|}
\hline Catalyst & $\begin{array}{c}\text { Number of Active } \\
\text { Sites from } \\
\text { CO-TPR } \\
\left(\mathbf{N}_{\mathrm{s}}\right) \\
\mathbf{x 1 0 ^ { - 3 }} \\
(\mathrm{mol} / \mathrm{g})\end{array}$ & $\begin{array}{r}\text { Kinetic } \\
\mathrm{CO}\end{array}$ & $\begin{array}{l}\text { ameters from } \\
{ }_{2} \mathrm{O} \text {-TPSR } \\
{\left[k_{\text {rds }}\right]_{400}{ }^{\circ} \mathrm{C}} \\
\times 10^{8} \\
\left(\mathrm{~s}^{-1}\right)\end{array}$ & $\begin{array}{c}\text { Activity } \\
\left(340^{\circ} \mathrm{C}\right) \\
\times 10^{-6} \\
(\mathrm{~mol} / \mathrm{s} \mathrm{g})\end{array}$ & $\begin{array}{c}\text { TOF } \\
\text { (Activity/N } \mathbf{N}_{\mathrm{s}} \text { ) } \\
\text { x10 } \\
\left(\mathrm{s}^{-1}\right)\end{array}$ & $\begin{array}{c}\text { Activation } \\
\text { Energy } \\
\left(\mathrm{E}_{\mathrm{a}}\right) \\
(\mathrm{kJ} / \mathrm{mol})\end{array}$ \\
\hline $3 \mathrm{Cu} 8 \mathrm{CrFe}$ & 0.74 & 182 & 5.1 & 6.9 & 9.3 & 69 \\
\hline 3Cu8CaFe & 0.22 & 142 & 47.5 & 10.0 & 45 & 50 \\
\hline 3Cu8NiFe & 0.76 & 185 & 4.3 & 8.9 & 12 & 60 \\
\hline $3 \mathrm{Cu} 8 \mathrm{CoFe}$ & 0.45 & 198 & 2.1 & 2.6 & 5.8 & 78 \\
\hline $3 \mathrm{Cu} 8 \mathrm{GeFe}$ & 1.52 & 275 & 0.03 & 0.71 & 0.5 & 36 \\
\hline
\end{tabular}

To correlate the redox ability of the catalysts with final SS-WGS activity, the reaction rate constant, for the rate-determining CO-oxidation step, at $400{ }^{\circ} \mathrm{C},\left[k_{\mathrm{rds}}\right]_{400}{ }^{\circ} \mathrm{C}$, was determined for each catalyst using information on $\left[\mathrm{T}_{\mathrm{p}}\right]_{\mathrm{rds}}$ and utilizing the Redhead expression for first-order desorption [30] (Equation (2)) and Arrhenius expression [31] (Equation (3)); this is included in Table 1 as well.

$$
\begin{gathered}
E_{d}=R T_{p}\left[\ln \left(\frac{A T_{p}}{\beta}\right)-3.64\right. \\
k_{r d s}=A \exp \left(\frac{-E_{d}}{R T}\right)
\end{gathered}
$$

In Equations (2) and (3), $A$ is the frequency factor $\left(10^{13} \mathrm{~s}^{-1}\right), \beta$ is the linear heating rate (in $\mathrm{K} / \mathrm{min}$ ), $E_{d}$ is the activation energy for desorption, and $R$ is the universal gas constant. For this purpose, the $\left[\mathrm{T}_{\mathrm{p}}\right]_{\text {rds }}$ was determined from $\mathrm{CO}+\mathrm{H}_{2} \mathrm{O}$ - TPSR spectroscopy, marked in Figure 4 and included in Table 1 . A plot of $\left[k_{\mathrm{rds}}\right]_{400}{ }^{\circ} \mathrm{C}$ multiplied by the number of surface sites $\left(\mathrm{N}_{\mathrm{s}}\right)$ (for r-WGS activated catalysts) and normalized by BET surface area vs. SS-WGS activity is shown in Figure 5. From Figure 5, with a slight exception for the $3 \mathrm{Cu} 8 \mathrm{NiFe}$ catalyst, all catalysts exhibit a linear relationship between redox ability of the catalytic active sites and the SS-activity.

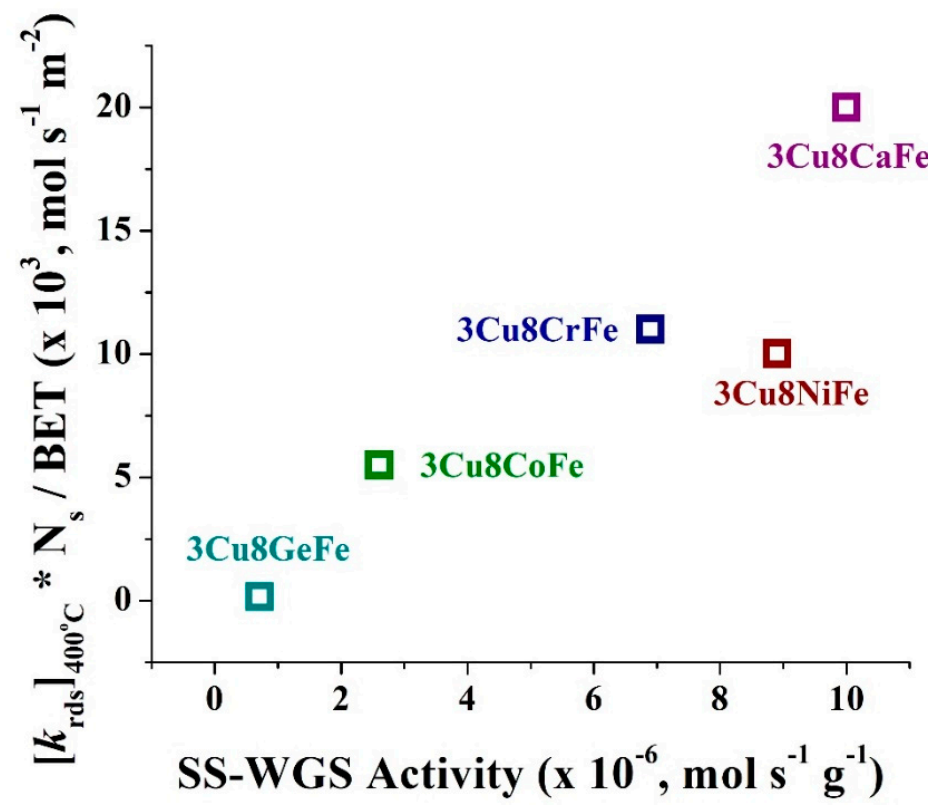

Figure 5. The plot of $\left[k_{\mathrm{rds}}\right]_{400}{ }^{\circ} \mathrm{C} * \mathrm{~N}_{\mathrm{s}} /$ BET vs. SS-WGS activity for the $3 \mathrm{Cu} 8 \mathrm{MFe}$ catalysts $(\mathrm{M}=\mathrm{Cr}, \mathrm{Ca}$, $\mathrm{Ni}, \mathrm{Co}$, and $\mathrm{Ge})$. 


\section{Discussion}

\subsection{Structure of Catalysts after Calcination and Activation with $r$-WGS Reaction}

Calcined catalysts: The characterization studies revealed that in the calcined catalysts, $\mathrm{Cu}$ is present as $\mathrm{Cu}^{+2}$ cations dissolved in the $\mathrm{Fe}_{2} \mathrm{O}_{3}$ lattice [7]. This is also supported by the equilibrium dissolution limit of $\mathrm{Cu}$ in the $\mathrm{Fe}_{2} \mathrm{O}_{3}$ phase (9 mol \% of $\mathrm{Cu} / \mathrm{mole}$ of $\mathrm{Fe}$ ) [32], which is much higher compared to $3.5 \mathrm{~mol} \%$ of $\mathrm{Cu}$ present in our catalysts per mole of Fe. The distribution of the promoters between the outermost surface layer and the subsurface layers, however, is dependent on the nature of each promoter. In the initially calcined catalyst, the oxide promoters are present in the outermost surface layer and subsurface layers. Whereas $\mathrm{Cr}, \mathrm{Ca}$, and Ge are surface enriched in the initial calcined catalysts, the $\mathrm{Ni}$ and Co promoters are surface depleted (see Figure 2). Studies show that $\mathrm{Cr}$ only in $\mathrm{Cr}$ (III) state can be dissolved in bulk $\mathrm{Fe}_{2} \mathrm{O}_{3}$ lattice and remaining $\mathrm{Cr}$ in $\mathrm{Cr}(\mathrm{VI})$ state (present due to the oxidizing environment for fresh catalyst) cannot be incorporated into $\mathrm{Fe}_{2} \mathrm{O}_{3}$ lattice, confirming the surface enrichment of $\mathrm{Cr}[7,29]$. Unfortunately, $\mathrm{Ca}$ (II) is incapable of substituting Fe(III) in the $\mathrm{Fe}_{2} \mathrm{O}_{3}$ phase, resulting in surface enrichment of $\mathrm{Ca}$ [29]. Only a very small amount of Ge ( 1 wt \%) can be dissolved in $\mathrm{Fe}_{2} \mathrm{O}_{3}$ phase [33], which is much lower compared to $\sim 5.5 \mathrm{wt} \%$ Ge present in our 3Cu8GeFe catalyst, causing surface enrichment of Ge. On the other hand, incorporation of $\mathrm{Ni}$ (II) and $\mathrm{Co}$ (III) up to $10 \mathrm{~mol} \%$ per mol $\mathrm{Fe}$ in $\mathrm{Fe}_{2} \mathrm{O}_{3}$ lattice has been achieved in the literature $[29,34,35]$. The approximate 9-10 mol \% of $\mathrm{Ni}$ and $\mathrm{Co}$, respectively, per mole of Fe present in our $3 \mathrm{Cu} 8 \mathrm{NiFe}$ and $3 \mathrm{Cu} 8 \mathrm{CoFe}$ catalysts confirms the solid solution of $\mathrm{Ni}$ and $\mathrm{Co}$ in bulk $\mathrm{Fe}_{2} \mathrm{O}_{3}$ lattice. A schematic of the catalyst structures for the initially calcined catalysts is shown in Scheme 1 (left).

Activated catalysts: After activation of the catalysts under WGS reaction mixture, the bulk $\mathrm{Fe}_{2} \mathrm{O}_{3}$ phase reduces to form $\mathrm{Fe}_{3} \mathrm{O}_{4}$ phase [6-9]. Interestingly, the dissolution limit of various promoters changes significantly in the $\mathrm{Fe}_{3} \mathrm{O}_{4}$ lattice compared to the $\mathrm{Fe}_{2} \mathrm{O}_{3}$ lattice [29]. $\mathrm{Cu}$ (II) is capable of migrating into the bulk $\mathrm{Fe}_{3} \mathrm{O}_{4}$ lattice [29]; however, the reducing environment of the WGS reaction retains $\mathrm{Cu}$ on the surface of the catalysts as $\mathrm{Cu}^{0}$ NPs [7]. For the $3 \mathrm{Cu} 8 \mathrm{CaFe}$ catalyst, the surface enrichment of $\mathrm{Ca}$ (see Figure 2) is consistent with the solubility limit of $\mathrm{Ca}$ in $\mathrm{Fe}_{3} \mathrm{O}_{4}$ [36]. The equilibrium solubility of $\mathrm{Ca}$ in $\mathrm{Fe}_{3} \mathrm{O}_{4}$ is $6.76 \mathrm{~mol} \% \mathrm{Ca} / \mathrm{mol} \mathrm{Fe}$ and the composition of the Ca-promoted catalyst was almost double at $12.6 \mathrm{~mol} \%$ of $\mathrm{Ca} / \mathrm{mol}$ of $\mathrm{Fe}$. The excess $\mathrm{Ca}$ above the solubility limit accounts for the surface enrichment of $\mathrm{Ca}$ in the activated $3 \mathrm{Cu} 8 \mathrm{CaFe}$ catalyst. For the $3 \mathrm{Cu} 8 \mathrm{NiFe}$ and $3 \mathrm{Cu} 8 \mathrm{CoFe}$ catalysts, after activation under r-WGS conditions, the HS-LEIS data show that both Ni and Co are surface depleted and make a solid solution with bulk $\mathrm{Fe}_{3} \mathrm{O}_{4}$ lattice. This is supported by the literature, reporting that $\sim 50 \mathrm{~mol} \%$ of $\mathrm{Ni}$ or $\mathrm{Co} / \mathrm{mol} \mathrm{Fe}$ can be incorporated in the $\mathrm{Fe}_{3} \mathrm{O}_{4}$ lattice [29], which is much higher than the amount ( $~ 9.5-10 \mathrm{~mol} \% \mathrm{Ni}$ or $\mathrm{Co} / \mathrm{mol} \mathrm{Fe})$ present in our catalysts. Although Ge is soluble in the $\mathrm{Fe}_{3} \mathrm{O}_{4}$ lattice [29], the solubility limit must be very low as observed by surface enrichment of $\mathrm{Ge}$ in the $3 \mathrm{Cu} 8 \mathrm{GeFe}$ catalyst. Unfortunately, we could not find any literature reporting the solubility data of $\mathrm{Ge}$ in the $\mathrm{Fe}_{3} \mathrm{O}_{4}$ lattice. A schematic of the catalyst structures and nature of the catalytic active site of the activated catalysts is shown in Scheme 1 (right). 


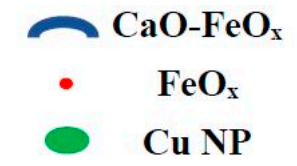

$\begin{array}{llll}\mathrm{CrO}_{3} & \mathrm{CrO}_{3} & \mathrm{CrO}_{3} & \mathrm{CrO}_{3}\end{array}$
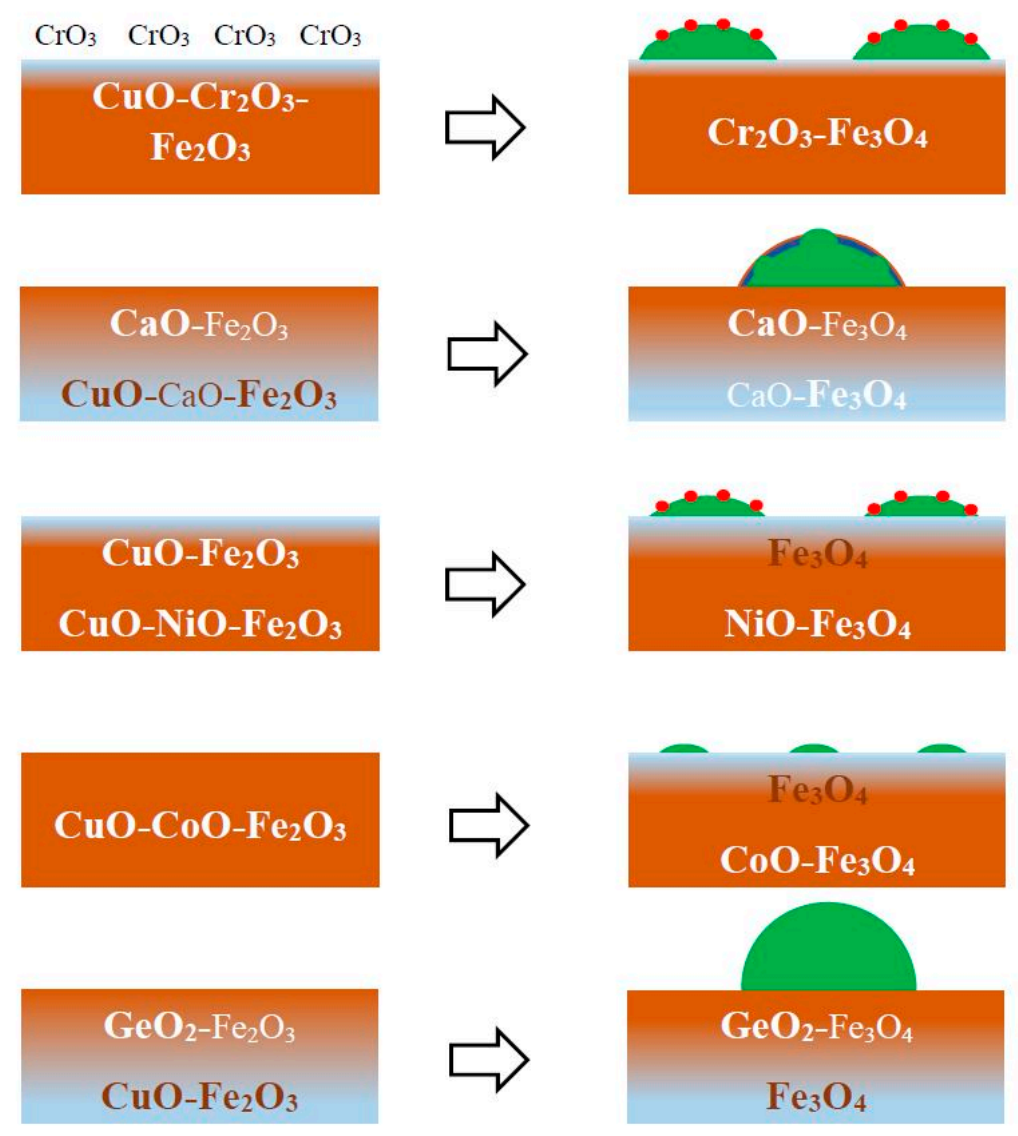

Before r-WGS
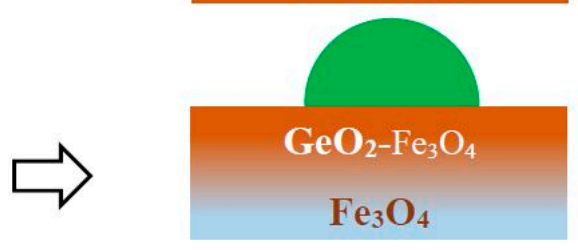

\section{After r-WGS}

Scheme 1. Structure and active site on the $3 \mathrm{Cu} 8 \mathrm{MFe}$ catalysts $(\mathrm{M}=\mathrm{Cr}, \mathrm{Ca}, \mathrm{Ni}, \mathrm{Co}$ and $\mathrm{Ge})$ before and after activation with r-WGS reaction mixture.

\subsection{Number of Catalytic Active Sites}

The number of catalytic active sites strongly depends on the capability of promoters to make solid solutions and their ability to stabilize the surface area of the $\mathrm{Fe}_{3} \mathrm{O}_{4}$ bulk phase against thermal and mechanical sintering. After activation under r-WGS reaction conditions (see Figure 2), only $\mathrm{Cr}, \mathrm{Ni}$, and Co promoters were able to make a complete solid solution with the $\mathrm{Fe}_{3} \mathrm{O}_{4}$ bulk phase. The $3 \mathrm{Cu} 8 \mathrm{CrFe}$ and $3 \mathrm{Cu} 8 \mathrm{NiFe}$ catalysts possess a similar amount of catalytic active sites (see Table 1) per gram of the catalyst, whereas the $3 \mathrm{Cu} 8 \mathrm{CoFe}$ catalyst has about $\sim 40 \%$ smaller number of active sites. Interestingly, the surface area of the $3 \mathrm{Cu} 8 \mathrm{CoFe}$ catalyst (after r-WGS treatment) is also much smaller compared to the $3 \mathrm{Cu} 8 \mathrm{CrFe}$ and $3 \mathrm{Cu} 8 \mathrm{NiFe}$ catalysts. A BET surface area normalized number of active sites for all the catalysts is presented in Table S1. From Table S1, it is clear that the promoters capable of forming complete solid solutions with $\mathrm{Fe}_{3} \mathrm{O}_{4}$ phase ( $\mathrm{Cr}$, Ni and $\mathrm{Co}$ ) contain a similar number of active sites per unit surface area of the catalyst. On the other hand, whereas only half of the Ca present in $3 \mathrm{Cu} 8 \mathrm{CaFe}$ catalyst forms a solid solution with $\mathrm{Fe}_{3} \mathrm{O}_{4}$ phase, almost all $\mathrm{Ge}$ in the $3 \mathrm{Cu} 8 \mathrm{GeFe}$ catalyst is surface enriched. Accordingly, the $3 \mathrm{Cu} 8 \mathrm{CaFe}$ catalyst possess a much smaller number of highly active catalytic sites (see Table S1) and the $3 \mathrm{Cu} 8 \mathrm{GeFe}$ catalyst does not contain a measurable amount of catalytic active 
sites with low-temperature activity (see Figure 3). The number of active sites for the 3Cu8GeFe catalyst presented in Table 1 and Table S1 are less active and are active at a much higher temperature.

\subsection{Reducibility and Redox Characteristics of Catalytic Active Sites}

Reducibility of the catalytic active sites is a strong function of the promoter's ability to form a solid solution with the $\mathrm{Fe}_{3} \mathrm{O}_{4}$ phase. All promoters, except $\mathrm{Ge}$, which forms a partial or complete solid solution with the $\mathrm{Fe}_{3} \mathrm{O}_{4}$ phase, are highly reducible (possess low-temperature $\mathrm{CO}$ - reduction peak, see Figure 3). On the other hand, Ge in the 3Cu8GeFe catalyst is completely surface enriched and very difficult to reduce (high CO-reduction peak temperature). Interestingly, the redox ability of these catalytic active sites is very different from its reducibility and depends on the type and nature of promotion of $\mathrm{Cu}^{0} \mathrm{NPs}$ present on the catalyst surface. $\mathrm{Ca}, \mathrm{Cr}$, and Ni helped catalysts form a thin oxide overlayer decorated on $\mathrm{Cu}^{0} \mathrm{NPs}$ on the respective catalyst surface (see Figure 2 and Scheme 1) and possess high redox ability (Figure 4 and Table 1 ). Co and Ge promoted catalysts, lack the advancement of $\mathrm{Cu}^{0} \mathrm{NPs}$ with oxide layers, and exhibit low redox ability.

\subsection{TOF Values}

The TOF exhibited by all the catalysts is a complex function of catalyst structure, number and nature of catalytic active sites, and SS-WGS performance. A summary for all the catalysts is given below:

3Cu8CaFe: Ca forms a partial solid solution (within its solubility limit) in the $\mathrm{Fe}_{3} \mathrm{O}_{4}$ phase, resulting in a highly reducible, but small amount of catalytic active sites. However, the decoration of $\mathrm{Cu}^{0} \mathrm{NPs}$ on the catalyst surface by both $\mathrm{Ca}$ and Fe-oxide phases creates a $\mathrm{Cu}-\mathrm{FeO}_{x} / \mathrm{CaO}_{x}$ highly active interfacial surface area and make the catalytic active sites extremely redox in nature. A small number of catalytic active sites with very high redox ability exhibit the highest SS-WGS performance, resulting in very high TOF.

$3 \mathrm{Cu} 8 \mathrm{NiFe}$ and $3 \mathrm{Cu} 8 \mathrm{CrFe}$ : Both $\mathrm{Ni}$ and $\mathrm{Cr}$ form a complete solid solution with the $\mathrm{Fe}_{3} \mathrm{O}_{4}$ bulk phase and stabilize the surface area effectively, resulting in a very high number of highly reducible catalytic active sites. In addition, both the promoters form $\mathrm{FeO}_{x}$ overlayers on the $\mathrm{Cu}^{0} \mathrm{NPs}$ on the respective catalyst surface, making the catalytic active sites highly redox in nature. A large number of active sites with high redox ability and high SS-WGS performance result in high TOF.

3Cu8CoFe: $\mathrm{Co}$ forms a complete solid solution with $\mathrm{Fe}_{3} \mathrm{O}_{4}$, but fails to stabilize the surface area against sintering, causing a highly reducible, but moderate amount of catalytic active sites. Further, the absence of interaction of active sites with $\mathrm{Cu}^{0} \mathrm{NPs}$ results in moderate redox ability. A moderate number of catalytic active sites with moderate redox ability exhibiting moderate to low SS-WGS activity results in a moderate TOF.

3Cu8GeFe: Ge is mostly surface enriched, possesses the highest number of active sites, but exhibits the lowest reducibility and redox ability. A high number of active sites with the least redox ability results in the lowest SS-WGS activity; catalytic sites possess the lowest TOF.

\subsection{HT-WGS Reaction Mechanism}

It is now well established in the literature that the HT-WGS reaction on an Fe oxide-based catalyst proceeds via a redox mechanism where the lattice oxygen atoms are periodically reduced and re-oxidized by $\mathrm{CO}$ and $\mathrm{H}_{2} \mathrm{O}$, respectively $[11,13,37]$. The $\mathrm{CO}+\mathrm{H}_{2} \mathrm{O}$-TPSR spectra demonstrate that all the promoted $\mathrm{Cu}-\mathrm{FeO}_{\mathrm{x}}$ catalysts were initially reduced by $\mathrm{CO}$ and subsequently oxidized by $\mathrm{H}_{2} \mathrm{O}$ to complete the redox catalytic cycle. The following facts support the conclusion that the WGS reaction proceeds via a redox mechanism.

(i) The evolution of $\mathrm{CO}_{2}$ and $\mathrm{H}_{2}$ occur at two different temperatures (redox mechanism) rather than simultaneously being involved from a common surface reaction intermediate (associative mechanism). 
(ii) At a relatively high temperature, when both $\mathrm{CO}_{2}$ and $\mathrm{H}_{2}$ evolution occur, the $\mathrm{H}_{2}$ formation is always retarded, compared to $\mathrm{CO}_{2}$ production; $\mathrm{H}_{2} / \mathrm{CO}_{2}$ ratio is less than 1 , which becomes $\sim 1$ at a much higher temperature $\left(>500^{\circ} \mathrm{C}\right)$ [37].

(iii) The comparison of SS-activity performance exhibited by all the catalysts show that the activity values follow the same trend (see Figure 5) as the degree of redox ability of the active sites observed from the $\mathrm{CO}+\mathrm{H}_{2} \mathrm{O}$ TPSR experiments, which is $3 \mathrm{Cu} 8 \mathrm{CaFe}>3 \mathrm{Cu} 8 \mathrm{NiFe} \sim 3 \mathrm{Cu} 8 \mathrm{CrFe}>$ $3 \mathrm{Cu} 8 \mathrm{CoFe}>>3 \mathrm{Cu} 8 \mathrm{GeFe}$.

\section{Experimental}

\subsection{Catalyst Synthesis and Activation}

The $\mathrm{CuO} / \mathrm{MO}_{\mathrm{x}}-\mathrm{Fe}_{2} \mathrm{O}_{3}$ ( $\mathrm{M}: \mathrm{Cr}, \mathrm{Ca}, \mathrm{Co}, \mathrm{Ni}$ and $\mathrm{Ge}$ ) catalysts investigated in this study were synthesized in two steps. In the first step, the ammonia assisted co-precipitation method was undertaken to prepare the $8 \mathrm{wt} \% \mathrm{MO}_{\mathrm{x}}-\mathrm{Fe}_{2} \mathrm{O}_{3}$ catalysts. Iron nitrate (Sigma Aldrich, St. Louis, $\mathrm{MO}$, USA, 99.99\% trace metal basis), chromium nitrate (Sigma Aldrich, St. Louis, MO, USA, 99.99\% trace metal basis), calcium nitrate (Sigma Aldrich, St. Louis, MO, USA, 99\% trace metal basis), cobalt nitrate (Alfa Aesar, Haverhill, MA, USA, 100\% trace metal basis), nickel nitrate (Alfa Aesar, Haverhill, MA, USA, 100\% trace metal basis), and germanium oxide (Alfa Aesar, Haverhill, MA, USA, 100\% trace metal basis) were chosen as metal oxide precursors. For catalyst preparation, the calculated amounts of corresponding metal nitrates (metal oxide in case of Ge) were mixed and dissolved in distilled and deionized water to which dilute ammonium hydroxide (EMD Millipore Corporation, Burlington, MA, USA, $28-30 \%$ by volume, $99.998 \%$ after ignited) was added dropwise with continuous stirring until the $\mathrm{pH}$ reached 8.5. (It should be mentioned that, for the preparation of $8 \mathrm{wt} \% \mathrm{GeO}_{2}-\mathrm{Fe}_{2} \mathrm{O}_{3}$ catalyst, the aqueous solution was prepared at an elevated temperature $\left(80^{\circ} \mathrm{C}\right)$ to ensure complete dissolution of $\mathrm{GeO}_{2}$ in water.) The dark brown precipitate formed was further aged for $24 \mathrm{~h}$ and filtered. The filtered precipitates were then dried at $80^{\circ} \mathrm{C}$ for $12 \mathrm{~h}$ and calcined at $400{ }^{\circ} \mathrm{C}$ for $4 \mathrm{~h}$ in a programmable oven under static air. The calcined catalysts were crushed into a fine powder and an incipient-wetness point was determined $(\sim 0.3-0.4 \mathrm{ml} / \mathrm{g})$. In the second step, the calculated amounts of the aqueous solution of $\mathrm{Cu}$ nitrate (Alfa Aesar, Haverhill, MA, USA, 100\% trace metal basis) were drop-wise impregnated to this powder to result in a final $3 \mathrm{wt} \% \mathrm{CuO}$ loading on $8 \mathrm{wt} \% \mathrm{MO}_{\mathrm{x}}-\mathrm{Fe}_{2} \mathrm{O}_{3}$ catalysts. The impregnated catalysts were subsequently dried overnight, followed by drying at $80^{\circ} \mathrm{C}$ for $12 \mathrm{~h}$ before final calcination at $400{ }^{\circ} \mathrm{C}$ for $4 \mathrm{~h}$ under static air. The prepared catalysts were assigned as $3 \mathrm{Cu} 8 \mathrm{MFe}(\mathrm{M}: \mathrm{Cr}, \mathrm{Ca}, \mathrm{Co}, \mathrm{Ni}, \mathrm{Ge})$; this notation will be used throughout the manuscript.

\subsection{Brunauer-Emmett-Teller (BET) Surface Area Determination}

The surface areas of the freshly calcined and r-WGS reaction mixture treated catalysts were determined by the 3-point BET method. A micromeritics ${ }^{\circledR}$ (Norcross, GA, USA) AutoChem II instrument equipped with a TCD detector was utilized to measure $\mathrm{N}_{2}$ (Airgas, Idaho Falls, ID, USA, UHP certified gas) adsorption/desorption amount for three different partial pressures $\left(\mathrm{P} / \mathrm{P}_{0}=0.15\right.$, $0.22,0.30$ ). Prior to measurement, fresh samples were heated at $\sim 150^{\circ} \mathrm{C}$ for $1 \mathrm{~h}$ under $30 \mathrm{~mL} / \mathrm{min} \mathrm{He}$ (Airgas, Idaho Falls, ID, USA, UHP certified gas) flow to remove any impurities. For surface area determination of the spent catalysts, the samples were first treated under r-WGS reaction mixture (10 $\mathrm{mL} / \mathrm{min}$ of $50 \% \mathrm{CO}_{2} / \mathrm{Ar}$ (Norco, Idaho Falls, ID, USA, certified standard, $50 \% \mathrm{CO}_{2} / \mathrm{Ar}$ ) and $50 \mathrm{~mL} / \mathrm{min}$ of $10 \% \mathrm{H}_{2} / \mathrm{Ar}$ (Norco, Idaho Falls, ID, USA, certified standard, $10.2 \% \mathrm{H}_{2} / \mathrm{Ar}$ ) with $\mathrm{CO}_{2}$ to $\mathrm{H}_{2}$ ratio 1) at $500{ }^{\circ} \mathrm{C}$ for $2 \mathrm{~h}$. After activation in an r-WGS reaction environment, the samples were degassed with $\mathrm{He}\left(30 \mathrm{~mL} / \mathrm{min}\right.$ for $1 \mathrm{~h}$ at $\left.150^{\circ} \mathrm{C}\right)$ prior to BET measurements.

\subsection{High-Sensitivity Low Energy Ion Scattering (HS-LEIS) Spectroscopy}

The outermost surface layers of the catalysts were analyzed with a Qtac ${ }^{100}$ (Chestnut Ridge, NY, USA) HS-LEIS spectrometer (ION-TOF) equipped with a highly sensitive double toroidal analyzer. 
The instrument provides 3000-fold higher sensitivity than conventional LEIS equipment, allowing for better quantitative static depth profiling. Prior to the initial spectroscopic measurement, the catalyst samples were dehydrated in static $\mathrm{O}_{2}$ (Airgas, Allentown, PA, USA, UHP certified gas, supplied by a balloon into the preparation chamber of the spectrometer) at $400{ }^{\circ} \mathrm{C}$ for $1 \mathrm{~h}$ to remove any possible adsorbed carbonaceous material and adsorbed moisture. After the dehydration step, the preparation chamber was evacuated, and the catalyst sample was transferred to the main UHV chamber for HS-LEIS analysis. To collect the surface information on activated catalysts after the r-WGS reaction, the dehydrated catalysts were further treated for $1 \mathrm{~h}$ under static $\mathrm{r}$-WGS reaction conditions $(\sim 100 \mathrm{mbar}$ $\mathrm{CO}_{2}$ (Airgas, Allentown, PA, USA, UHP certified gas) and $\sim 100$ mbar $\mathrm{H}_{2}$ (Airgas, Allentown, PA, USA, UHP certified gas)) at $400{ }^{\circ} \mathrm{C}$. The design of the preparation chamber on the HS-LEIS spectrometer prevents the pre-treated catalysts from coming in contact with the atmosphere when being transferred into the main UHV analysis chamber. The HS-LEIS depth profiling spectrum was collected using $3 \mathrm{keV}$ $\mathrm{He}^{+}$and $5 \mathrm{keV} \mathrm{Ne}{ }^{+}$as the ion sources. For deeper depth profiling, the surface was sputtered with $0.5 \mathrm{keV} \mathrm{Ar}{ }^{+}$with each sputter and measurement cycle yielding a total of $1 \times 10^{15} \mathrm{ions} / \mathrm{cm}^{2}$, which corresponds to $\sim 1$ atomic layer $(\sim 0.3 \mathrm{~nm})$.

\section{4. $\mathrm{CO}-\mathrm{TPR}$ and $\mathrm{CO}+\mathrm{H}_{2} \mathrm{O}$ TPSR Spectroscopy}

The CO-TPR and $\mathrm{CO}+\mathrm{H}_{2} \mathrm{O}$ TPSR experiments were performed in an Altamira Instruments system (AMI-200, Pittsburgh, PA, USA). For the temperature-programmed experiments, approximately $30 \mathrm{mg}$ of the catalyst sample was mounted on one limb of a quartz U-tube reactor that was first dehydrated under $10 \% \mathrm{O}_{2} / \mathrm{Ar}$ (Praxair, Allentown, PA, USA, Certified Standard, $10 \% \mathrm{O}_{2} /$ Ar balance) at $400{ }^{\circ} \mathrm{C}$ for $1 \mathrm{~h}$. Afterwards, the catalyst samples were activated under WGS reaction conditions $(10 \mathrm{~mL} / \mathrm{min} 10 \%$ $\mathrm{CO} / \mathrm{Ar}$ (Praxair, Allentown, PA, USA, Certified Standard, 9.9\% CO/Ar balance) and $30 \mathrm{~mL} / \mathrm{min} \mathrm{He}$ (Airgas, Allentown, PA, USA, UHP certified gas) flowing through a bubbler to carry $2.5 \%$ water vapor $\left.\left(\mathrm{H}_{2} \mathrm{O} / \mathrm{CO} 1\right)\right)$ at $400{ }^{\circ} \mathrm{C}$ for $90 \mathrm{~min}$. After the catalyst was activated, the reactor was flushed with $\mathrm{He}$ and cooled to $80^{\circ} \mathrm{C}$. To conduct CO-TPR experiments, a flow of $30 \mathrm{~mL} / \mathrm{min} 10 \% \mathrm{CO} /$ Ar was introduced with a temperature ramp of $10{ }^{\circ} \mathrm{C} / \mathrm{min}$ up to $450{ }^{\circ} \mathrm{C}$. For $\mathrm{CO}+\mathrm{H}_{2} \mathrm{O}$ TPSR experiments, a flow of 10 $\mathrm{mL} / \mathrm{min} 10 \% \mathrm{CO} / \mathrm{Ar}$ and $30 \mathrm{~mL} / \mathrm{min} \mathrm{He}$, flowing through bubbler at room temperature, was then introduced with the temperature ramping up to $450{ }^{\circ} \mathrm{C}$ at a rate of $10^{\circ} \mathrm{C} / \mathrm{min}$. The gases flowing out of the reactor were analyzed by an online quadrupole mass spectrometer (AMETEK, Dycor Dymaxion DME100MS, Berwyn, PA, USA).

\subsection{SS-WGS Activity}

The steady-state activity of the HT-WGS catalytic reaction was measured in an Altamira Instruments system (AMI-200). For this experiment, approximately $10 \mathrm{mg}$ of catalyst samples were first dehydrated, followed by activation under the WGS reaction conditions as described above for the $\mathrm{CO}+\mathrm{H}_{2} \mathrm{O}$ TPSR experiment. The activated catalysts were then treated in a reaction mixture of $10 \% \mathrm{CO} / \mathrm{Ar}(10 \mathrm{ml} / \mathrm{min})$ and water vapor $\left(\mathrm{H}_{2} \mathrm{O} / \mathrm{CO} 1\right)$ via $\mathrm{He}(30 \mathrm{ml} / \mathrm{min})$ flowing through the water bubbler at $25{ }^{\circ} \mathrm{C}$. The reaction was performed at $340{ }^{\circ} \mathrm{C}$ to ensure low conversions $(<10 \%)$ and the steady-state WGS reaction data were taken $2 \mathrm{~h}$ after the experiment. The outgoing gases were analyzed by an online quadrupole mass spectrometer (Dycor Dymaxion DME100MS). The SS activities at two higher temperatures $\left(360^{\circ} \mathrm{C}\right.$ and $\left.380^{\circ} \mathrm{C}\right)$ were also measured to find out the activation energy for the reaction using the Arrhenius expression.

\section{Conclusions}

A series of 3Cu8MFe catalysts were synthesized by a two-step co-precipitation, followed by the incipient-wetness impregnation method to test the performance of the $\mathrm{Cr}$-free promoters for an HT-WGS reaction. The HS-LEIS surface analysis characterization and CO-TPR, $\mathrm{CO}+\mathrm{H}_{2} \mathrm{O}$ TPSR and SS-WGS activity experiments were conducted to understand the catalyst structure, nature of the active site, structure-function relationship, and the HT-WGS reaction mechanism. It was found that both Ca 
and Ni promote the formation of highly active $\mathrm{FeO}_{x}-\mathrm{Cu}$ interfacial areas and exhibit better SS-WGS activity, compared to the $3 \mathrm{Cu} 8 \mathrm{CrFe}$ catalyst. The $\mathrm{Co}$ and Ge promoters, however, lack the ability to promote the $\mathrm{FeO}_{x}-\mathrm{Cu}$ interface and perform poorly for the HT-WGS reaction. These activity findings are related to the ability of the promoters to form solid solutions with the $\mathrm{Fe}_{3} \mathrm{O}_{4}$ support $(\mathrm{Cr}$, $\mathrm{Ni}$ and $\mathrm{Ca}$ ); promoters that do not stabilize the $\mathrm{Fe}_{3} \mathrm{O}_{4}$ surface area (Co); and promoters that do not dissolve in $\mathrm{Fe}_{3} \mathrm{O}_{4}$ $(\mathrm{Ge})$, segregate at the surface, and minimize formation of $\mathrm{FeO}_{x}-\mathrm{Cu}$ interfacial sites. This suggests that $\mathrm{FeO}_{\mathrm{x}}-\mathrm{Cu}$ interfacial sites are active sites for $3 \mathrm{Cu} 8 \mathrm{MFe}$ catalysts. The role of $\mathrm{FeO}_{\mathrm{x}}-\mathrm{Cu}$ interfacial sites was further elaborated upon by correlating redox ability with SS-WGS performance. Consequently, both redox ability and SS-WGS performance follow the same trend: $3 \mathrm{Cu} 8 \mathrm{CaFe}>3 \mathrm{Cu} 8 \mathrm{NiFe} \geq 3 \mathrm{Cu} 8 \mathrm{CrFe}$ $>3 \mathrm{Cu} 8 \mathrm{CoFe}>>3 \mathrm{Cu} 8 \mathrm{GeFe}$. This trend reveals that both $\mathrm{Ca}$ and $\mathrm{Ni}$ can be utilized as substitutes for the toxic Cr promoter in the HT-WGS catalyst. Furthermore, all the catalysts follow the redox-type reaction mechanism for the HT-WGS reaction.

Supplementary Materials: The following are available online at http://www.mdpi.com/2073-4344/10/3/305/s1, Figures S1-S5 and Table S1.

Author Contributions: Conceptualization, S.S. and I.E.W.; Data curation, S.S.; Formal analysis, S.S. and I.E.W.; Funding acquisition, I.E.W.; Investigation, S.S.; Supervision, I.E.W.; Writing—original draft, S.S.; Writing—review \& editing, I.E.W. All authors have read and agreed to the published version of the manuscript.

Funding: The authors acknowledge financial support from the National Science Foundation Grant CBET-1511689.

Acknowledgments: The authors are thankful to Henry Luftman of Lehigh University for help in generating the HS-LEIS data, Jih-Mirn Jheng of National Chung Hsing University for help in running the CO+ $\mathrm{H}_{2} \mathrm{O}-\mathrm{TPSR}$ measurements, and Rebecca R. Fushimi of Idaho National Laboratory for providing instrument time (supported by the U.S. Department of Energy (USDOE), Office of Energy Efficiency and Renewable Energy (EERE), Advanced Manufacturing Office Next Generation R\&D Projects under contract no. DE-AC07-05ID14517) for BET surface area measurements of the catalysts.

Conflicts of Interest: The authors declare no conflict of interest.

\section{References}

1. Ridler, D.E.; Twigg, M.V. Catalyst Handbook, 2nd ed.; CRC Press: Boca Raton, FL, USA, 1996.

2. Satterfield, C.N. Heterogeneous Catalysis in Industrial Practice, 2nd ed.; McGraw Hill Book Co.: New York, NY, USA, 1991.

3. Newsome, D.S. The Water-Gas Shift Reaction. Catal. Rev. 1980, 21, 275-318. [CrossRef]

4. Ratnasamy, C.; Wagner, J.P. Water Gas Shift Catalysis. Catal. Rev. 2009, 51, 325-440. [CrossRef]

5. Chinchen, G.C.; Logan, R.H.; Spencer, M.S. Water-Gas Shift Reaction over an Iron Oxide/Chromium Oxide Catalyst.: II: Stability of Activity. Appl. Catal. 1984, 12, 89-96. [CrossRef]

6. Patlolla, A.; Carino, E.V.; Ehrlich, S.N.; Stavitski, E.; Frenkel, A.I. Application of Operando XAS, XRD, and Raman Spectroscopy for Phase Speciation in Water Gas Shift Reaction Catalysts. ACS Catal. 2012, 2, 2216-2223. [CrossRef]

7. Zhu, M.; Rocha, T.C.R.; Lunkenbein, T.; Knop-Gericke, A.; Schlögl, R.; Wachs, I.E. Promotion Mechanisms of Iron Oxide-Based High Temperature Water-Gas Shift Catalysts by Chromium and Copper. ACS Catal. 2016, 6, 4455-4464. [CrossRef]

8. Keturakis, C.J.; Zhu, M.; Gibson, E.K.; Daturi, M.; Tao, F.; Frenkel, A.I.; Wachs, I.E. Dynamics of CrO3-Fe2O3 Catalysts during the High-Temperature Water-Gas Shift Reaction: Molecular Structures and Reactivity. ACS Catal. 2016, 6, 4786-4798. [CrossRef]

9. Zhu, M.; Yalçın, Ö.; Wachs, I.E. Revealing Structure-Activity Relationships in Chromium Free High Temperature Shift Catalysts Promoted by Earth Abundant Elements. Appl. Catal. B Environ. 2018, 232, 205-212. [CrossRef]

10. Tauster, S.J. Strong Metal-Support Interactions. Acc. Chem. Res. 1987, 20, 389-394. [CrossRef]

11. Zhu, M.; Tian, P.; Kurtz, R.; Lunkenbein, T.; Xu, J.; Schlögl, R.; Wachs, I.E.; Han, Y.-F. Strong Metal-Support Interactions between Copper and Iron Oxide during the High-Temperature Water-Gas Shift Reaction. Angew. Chem. Int. Ed. 2019, 58, 9083-9087. [CrossRef]

12. Zhu, M.; Wachs, I.E. Determining Number of Active Sites and TOF for the High-Temperature Water Gas Shift Reaction by Iron Oxide-Based Catalysts. ACS Catal. 2016, 6, 1764-1767. [CrossRef] 
13. Polo-Garzon, F.; Fung, V.; Nguyen, L.; Tang, Y.; Tao, F.; Cheng, Y.; Daemen, L.L.; Ramirez-Cuesta, A.J.; Foo, G.S.; Zhu, M.; et al. Elucidation of the Reaction Mechanism for High-Temperature Water Gas Shift over an Industrial-Type Copper-Chromium-Iron Oxide Catalyst. J. Am. Chem. Soc. 2019, 141, 7990-7999. [CrossRef] [PubMed]

14. Domka, F.; Łaniecki, M. The Role of Cr2O3 in Catalyst for Water-Gas Shift Reaction. Z. Anorg. Allg. Chem. 1977, 435, 273-283. [CrossRef]

15. Lee, D.-W.; Lee, M.S.; Lee, J.Y.; Kim, S.; Eom, H.-J.; Moon, D.J.; Lee, K.-Y. The Review of Cr-Free Fe-Based Catalysts for High-Temperature Water-Gas Shift Reactions. Catal. Today 2013, 210, 2-9. [CrossRef]

16. Zhu, M.; Wachs, I.E. Iron-Based Catalysts for the High-Temperature Water-Gas Shift (HT-WGS) Reaction: A Review. ACS Catal. 2016, 6, 722-732. [CrossRef]

17. Zhu, M.; Wachs, I.E. A Perspective on Chromium-Free Iron Oxide-Based Catalysts for High Temperature Water-Gas Shift Reaction. Catal. Today 2018. [CrossRef]

18. Chinchen, G.C. EP Patent EP0062410 B1, 1986.

19. Rethwisch, D.G.; Dumesic, J.A. The Effects of Metal-Oxygen Bond Strength on Properties of Oxides: II. Water-Gas Shift over Bulk Oxides. Appl. Catal. 1986, 21, 97-109. [CrossRef]

20. Pereira, A.L.; dos Santos, N.A.; Ferreira, M.L.; Albornoz, A.; do Carmo Rangel, M. Effect of Cobalt on the Activity of Iron-Based Catalysts in Water Gas Shift Reaction. In Natural Gas Conversion VIII.; Bellot Noronha, F., Schmal, M., Falabella Sousa-Aguiar, E., Eds.; in Studies in Surface Science and Catalysis; Elsevier: San Diego, CA, USA, 2007; Volume 167, pp. 225-230. [CrossRef]

21. Lee, J.Y.; Lee, D.-W.; Lee, K.-Y.; Wang, Y. Cr-Free Fe-Based Metal Oxide Catalysts for High Temperature Water Gas Shift Reaction of Fuel Processor Using LPG. Catal. Today 2009, 146, 260-264. [CrossRef]

22. Lee, J.Y.; Lee, D.-W.; Hong, Y.-K.; Lee, K.-Y. The CO Removal Performances of Cr-Free Fe/Ni Catalysts for High Temperature WGSR under LNG Reformate Condition without Additional Steam. Int. J. Hydrog. Energy 2011, 36, 8173-8180. [CrossRef]

23. Lee, J.Y.; Lee, D.-W.; Lee, M.S.; Lee, K.-Y. Cs-Promoted Ni/Fe Catalyst as a Cr-Free, High Temperature Shift Catalyst for Steam Methane Reformate without Additional Supply of Steam. Catal. Commun. 2011, 15, 37-40. [CrossRef]

24. Jha, A.; Jeong, D.-W.; Shim, J.-O.; Jang, W.-J.; Lee, Y.-L.; Rode, C.V.; Roh, H.-S. Hydrogen Production by the Water-Gas Shift Reaction Using CuNi/ $\mathrm{Fe}_{2} \mathrm{O}_{3}$ Catalyst. Catal. Sci. Technol. 2015, 5, 2752-2760. [CrossRef]

25. de Araújo, G.C.; do Carmo Rangel, M. An Environmental Friendly Dopant for the High-Temperature Shift Catalysts. Catal. Today 2000, 62, 201-207. [CrossRef]

26. Jeong, D.-W.; Subramanian, V.; Shim, J.-O.; Jang, W.-J.; Seo, Y.-C.; Roh, H.-S.; Gu, J.H.; Lim, Y.T. High-Temperature Water Gas Shift Reaction Over Fe/Al/Cu Oxide Based Catalysts Using Simulated Waste-Derived Synthesis Gas. Catal. Lett. 2013, 143, 438-444. [CrossRef]

27. Jang, W.-J.; Shim, J.-O.; Jeon, K.-W.; Na, H.-S.; Kim, H.-M.; Lee, Y.-L.; Roh, H.-S.; Jeong, D.-W. Design and Scale-up of a Cr-Free Fe-Al-Cu Catalyst for Hydrogen Production from Waste-Derived Synthesis Gas. Appl. Catal. B Environ. 2019, 249, 72-81. [CrossRef]

28. Damma, D.; Jampaiah, D.; Welton, A.; Boolchand, P.; Arvanitis, A.; Dong, J.; Smirniotis, P.G. Effect of Nb Modification on the Structural and Catalytic Property of $\mathrm{Fe} / \mathrm{Nb} / \mathrm{M}(\mathrm{M}=\mathrm{Mn}, \mathrm{Co}, \mathrm{Ni}$, and $\mathrm{Cu}$ ) Catalyst for High Temperature Water-Gas Shift Reaction. Catal. Today 2019. [CrossRef]

29. Cornell, R.M.; Schwertmann, U. The Iron Oxides: Structure, Properties, Reactions, Occurrences and Uses; John Wiley \& Sons: Hoboken, NJ, USA, 2003.

30. Redhead, P.A. Thermal Desorption of Gases. Vacuum 1962, 12, 203-211. [CrossRef]

31. Laidler, K.J. The Development of the Arrhenius Equation. J. Chem. Educ. 1984, 61, 494. [CrossRef]

32. Cornell, R.M.; Giovanoli, R. The Influence of Copper on the Transformation of Ferrihydrite $\left(5 \mathrm{Fe}_{2} \mathrm{O}_{3} 9 \mathrm{H}_{2} \mathrm{O}\right)$ into Crystalline Products in Alkaline Media. Polyhedron 1988, 7, 385-391. [CrossRef]

33. Bernstein, L.R.; Waychunas, G.A. Germanium Crystal Chemistry in Hematite and Goethite from the Apex Mine, Utah, and Some New Data on Germanium in Aqueous Solution and in Stottite. Geochim. Cosmochim. Acta 1987, 51, 623-630. [CrossRef]

34. Shannon, R.D.; Prewitt, C.T. Effective Ionic Radii in Oxides and Fluorides. Acta Crystallogr. Sect. B 1969, 25, 925-946. [CrossRef] 
35. Singh, B.; Sherman, D.M.; Gilkes, R.J.; Wells, M.; Mosselmans, J.F.W. Structural Chemistry of Fe, Mn, and Ni in Synthetic Hematites as Determined by Extended X-Ray Absorption Fine Structure Spectroscopy. Clays Clay Miner. 2000, 48, 521-527. [CrossRef]

36. de Sitter, J.; Govaert, A.; de Grave, E.; Chambaere, D.; Robbrecht, G. A Mössbauer Study of Ca ${ }^{2+}$ _Containing Magnetites. Phys. Status Solidi 1977, 43, 619-624. [CrossRef]

37. Zhu, M.; Wachs, I.E. Resolving the Reaction Mechanism for $\mathrm{H}_{2}$ Formation from High-Temperature Water-Gas Shift by Chromium-Iron Oxide Catalysts. ACS Catal. 2016, 6, 2827-2830. [CrossRef]

(C) 2020 by the authors. Licensee MDPI, Basel, Switzerland. This article is an open access article distributed under the terms and conditions of the Creative Commons Attribution (CC BY) license (http://creativecommons.org/licenses/by/4.0/). 